Research Report No. 16/2007

\title{
Introduction: Regulating Markets and Social Europe: New Governance in the EU
}

Imelda Maher

Follow this and additional works at: http:/ / digitalcommons.osgoode.yorku.ca/clpe

\section{Recommended Citation}

Maher, Imelda, "Introduction: Regulating Markets and Social Europe: New Governance in the EU" (2007). Comparative Research in Law \& Political Economy. Research Paper No. 16/2007.

http://digitalcommons.osgoode.yorku.ca/clpe/233 


\section{Comparative Research in Law \& Political Economy}

Imelda Maher

Introduction - Regulating Markets and Social Europe: New Governance in the EU

EDITORS: Peer Zumbansen (Osgoode Hall Law School, Toronto, Director, Comparative Research in Law and Political Economy, York University), J ohn W. Cioffi (University of California at Riverside), Lindsay Krauss (Osgoode Hall Law School, Toronto, Production Editor) 

CLPE Research Paper 16/2007

Vol. 03 No. 05 (2007)

Special Symposium Issue:

EU Governance

\section{ProceEdingS FROM THE $10^{\mathrm{TH}}$ IRISH EU LAW FORUM} UNIVERSITY COLLEGE DUBLIN, 19 JANUARY 2007

\section{Contents of this Symposium:}

Imelda Maher

Colin Scott

Blanaid Clarke

Gavin Barrett

Simon Deakin

Peer Zumbansen
INTRODUCTION: REGULATING MARKETS AND SOCIAL EUROPE: NEW GOVERNANCE IN THE EU

NEW-ISH GOVERNANCE AND THE LEGITIMACY OF THE EU

TAKEOVER REGULATION: THROUGH THE REGULATORY LOOKING GLASS

DELIVERING A COMMUNITY EMPLOYMENT LAW: A TALE OF TWO MECHANISMS

REFLEXIVE GOVERNANCE AND EUROPEAN COMPANY LAW

VARIETIES OF CAPITALISM AND THE LEARNING FIRM: CONTEMPORARY DEVELOPMENTS IN EU AND GERMAN COMPANY LAW 
CLPE Research Paper 16/2007

Vol. 03 No. 05 (2007)

Special Symposium Issue:

EU Governance

PROCEEDINGS FROM THE $10^{\mathrm{TH}}$ IRISH EU LAW FORUM, UNIVERSITY COLLEGE

DUBLIN, 19 JANUARY 2007

\section{Imelda Maher}

\section{INTRODUCTION: REgULATING MARKETS AND SOCIAL EUROPE: \\ NEW GOVERNANCE IN THE EU}

Keywords: EU governance, corporate governance, methods of governance

JEL classification: K22, K33

Author Contact: Imelda Maher Sutherland Professor of European Law University College Dublin School of Law Roebuck Castle, Belfield, Dublin 4, Ireland

Email: imelda.maher@ucd.ie 




\title{
REgUlating MARKETS AND SOCIAL EUROPE: NEW GOVERNANCE IN THE EU
}

\author{
Imelda Maher ${ }^{*}$
}

\section{INTRODUCTION}

Governance understood as the diffusion and fragmentation of governmental arrangements is exemplified by the multi-level governance structures of the EU itself. Since its foundation, its supra-national character led to policy formation and implementation at different levels of government. More recently, and partly as a result of recognition of the extent to which the EU is more dependent on regulation as an instrument of governance than traditional state polities, ${ }^{1}$ there has been a reconceptualisation of both the methods and instruments of governing at the European level. Initially, innovation was triggered by the Single European Act which both introduced framework directives where detailed regulatory specifications were no longer set out at the European level but were in many instances delegated to private standard setting bodies ${ }^{2}$ and which started the ongoing (and often politically contentious) liberalisation programme. $^{3}$ The liberalisation of energy and communications industries that previously were state monopolies combined competition and regulation with the emergence of enforcement agencies in turn spurring the creation of a patchwork of agency networks across Europe. ${ }^{4}$

\footnotetext{
* UCD Law School.

${ }^{1}$ G. Majone, 'Market Integration and Regulation: Europe after 1992' (1992) 43 Metroeconomica 131

${ }^{2}$ H. Schepel, The Constitution of Private Governance: Product Standards ain the Regulation of Integrating Markets Oxford, Hart (2005).

${ }^{3}$ C. Scott, 'Changing Patterns of European Community Utilities Law and Policy: An Institutional Hypothesis' in J. Shaw and G. More (eds.) New Legal Dynamics of European Union Oxford University Press, Oxford (1996).

${ }^{4}$ D. Coen and M. Thatcher, 'Network Governance and Delegation: European Networks of Regulatory Agencies' (2007) Regulation and Governance.
} 
Under the Lisbon process ${ }^{5}$ newer forms of governance have emerged. Like the Single Market Programme these were linked to a deadline and an objective but unlike that programme, the governance methods, captured under the umbrella term 'the open method of coordination' were primarily based on policy learning, reporting and the issuance of guidelines all firmly within the realm of soft law $^{6}$ which may or may not result in binding legal measures. ${ }^{7}$ This departs from the classic Monnet method where the Commission proposes legislation which is adopted by the Council (and now under co-decision with the European Parliament), although the privatisation of standard-setting under the Single Act marked an earlier departure from this classic approach. Both Lisbon and the Single Market are underpinned by competition and competitiveness, with a competitiveness Council of Ministers being set up post-Lisbon. Competitiveness implies a more dirigiste industrial policy and is sometimes seen as undermining competition although in the EU competition policy with a strong economics-based rationale is seen as dominating policy formation leading to tensions on at least two planes. First, politically the French 'no' in part is seen as due to opposition to the perceived liberal market agenda of the EU. This in part may explain the French insistence on the removal of a reference to free competition in Article 4 of the EC Treaty. Second, the potential tension between competition and competitiveness reflects the search for a balance between

\footnotetext{
${ }^{5}$ The core objective as articulated by the European Council in Lisbon in 2000 was to make Europe the most competitive and dynamic knowledge-based economy in the world, capable of sustaining economic growth with more and better jobs and greater social cohesion with a deadline of 2010. This has now been reduced to growth and jobs and the deadline has been dropped see generally, EC Commission, Delivering on Growth and Jobs: A New and Integrated Economic and Employment Co-ordination Cycle in the EU, SEC(2005) 193, Brussels, 3.2.2005.

${ }^{6}$ Where soft law is seen as measures which are non-binding but are capable (and may even be intended to have) binding effects see F. Snyder, 'The Effectiveness of European Community Law: Institutions, Processes, Tools and Techniques, in Daintith, Terence, (ed.) Implementing EC Law in the United Kingdom: Structures for Indirect Rule (1995, Chichester: Wiley) at 64.

${ }^{7}$ D. Hodson, and I. Maher, 'The Open Method as a New Mode of Governance: The Case of Soft Economic Policy Co-ordination’ (2001) 39(4) Journal of Common Market Studies 719
} 
structural reform - which goes to the heart of the Lisbon agenda - and what can loosely be described as 'social Europe'.

The authors in this series of papers address these two phenomena of the relationship between 'new' and 'old' governance and the tensions between the 'market' defined in terms of strong competition policy and social Europe. The first paper by Scott provides an overview of the nature of new governance and addresses the vexed - and the long-standing - issue of legitimacy. This is followed by two substantive papers. Clarke examines the Takeover Directive and the extent to which its flexibility has impeded its original objective of improving European international competitiveness. Barrett then looks at 'Social Europe' examining two different governance methods and their limitations. The last two papers build on these two substantive fields with Deakin examining whether or not there is asymmetric governance between market regulation and social Europe (in this instance European company law and labour law) while Zumbansen through an exploration of European and German company law offers further insights into the issue of diversity in corporate governance in Europe and its re-assertion following problems in securing harmonisation and in the process explores the nature of the firm looking, like Deakin at both corporate governance and labour law.

Colin Scott sets the scene for the papers that follow by contrasting more traditional conceptions of EU governance with an analysis of the variety of forms of 'new governance' arguing that some of the more innovative modes of governance are not in fact so new while some of the more recent modes of governance while new are not that innovative. The question he addresses is whether this limited conception of new governance is inevitable given the legitimacy constraints within which the EU operates or whether there is potential for developing a broader conception of governance which through wider participation and involvement of nongovernmental governing capacities might bolster legitimacy through both better processes and better outcomes. The diffusion of governing capacity, a hallmark of governance, has important implications for what type of instrument is possible as binding legal instruments are usually only available to central government. At the same time, non-governmental actors can do things that are not possible - or legitimate - for governmental actors. Thus the fragmentation of governance calls into question the focus on legitimation through democratic mechanisms, where 
legitimacy is conceived of as decision which command support and are followed by those affected by them whether or not they agree with them. Because of the chronic democratic deficit in the EU, legitimacy has been predicated on outputs to a much grater degree than within states. Thus he argues that evaluation of legitimacy of emerging governance methods might examine the extent to which non-governmental actors and processes are engaged with markets and communities (alternative forms of accountability well-rehearsed in the regulation literature), seen as offering alternative legitimation mechanisms. The shift from law-based to network-based governance is not that innovative as opportunities to better engage with non-governmental capacities have been neglected or restricted in part by concerns for democratic legitimacy.

Blanaid Clarke examines the goals and achievements of the Takeover Directive which arose out of concerns for European competitiveness with an integrated European capital market seen as an important dimension of improving international competitiveness. The paper paints a bleak picture of failure to realise those objectives and how diversity remains. There is some light at the end of the proverbial tunnel with the issue of diverse national regimes analysed further by both Deakin and Zumbansen. Clarke notes that the directive in fact does not increase international competitiveness - largely due to the protectionist attitude of a large number of Member States in their implementation of it. It does provide a minimum standard but for those states that already had those standards there is no benefit and even the possibility of greater uncertainty. While arguably the directive provides a useful structure for new Member States, this is not essential as there are examples of states who introduced national takeover regimes before the Directive. The long history of the Directive also highlights the potential for policy learning - usually associated with soft law regimes - at the national level even where there is a failure to adopt legislation at the EU level with German law incorporating a mandatory bid rule despite having resisted such a measure in earlier EC proposals. She also notes the difficulties of moving from a voluntary (and effective) system in the UK to one requiring statutory foundation potentially reducing flexibility and, by implication, effectiveness and this despite the emphasis on flexibility within the Directive itself. By opting for a basic principles model the Directive ensures that takeover regulation will vary at national level. This retains the scope for regulatory innovation and, given that variation generates regulatory competition, may lead to 
specialisation in different national regimes rather than convergence across regimes. At the same time, use is made of soft law instruments: notably the Recommendation on the Role of Non-Executive or Supervisory Directors of Listed Companies and on the Committees of the (Supervisory) Boards. While Clarke concedes that soft law is appropriate where one size cannot fit all, there is a problem with some aspects of corporate governance falling between regulatory stools thereby undermining legitimacy as the EC creates expectations (e.g. of a level playing field and common set of rules for takeovers) which it cannot meet.

Gavin Barrett explores how elusive consensus has proved for EU social policy and the impact this has had on the governance methods chosen: focussing on the European social dialogue and legislation with effectiveness and input legitimacy (in particular in relation to the range of voices heard) central concerns in his analysis. Social dialogue is a Treaty-based policy making process whereby management and employee representatives cooperate in policy and law making. The process has had some successes in leading to legislation and some failures leading to the perception that the Open Method was needed to achieve EC goals. Barrett identifies the process as flexible: leading to an extraordinary range of outcomes; evolving, with a major role of the Commission and a weak role for the Parliament. The challenges for the partnership: lack of transparency, lack of openness to other non-governmental actors once agreement is reached and the challenges of enlargement are also outlined. Looking at a specific piece of legislation - the Acquired Rights Directive - Barrett notes the long history of its adoption exacerbated by the need for unanimity. This in turn led to omissions designed to ensure sufficient consensus for adoption which propels the European Court in its interpretative role, into the role of quasi-lawmaker. The discussion points to the potential for ambiguity and lack of precision in the text - criticism normally raised (as seen in Clarke's paper) in relation to soft law instruments. The difference between the two forms of law being that the Court remains as final arbiter where the ambiguity lies in legislation. Barrett's paper explores the implementation of the Directive in the Irish context noting the importance that flows from the chosen method of implementation, the potential that implementation has to disrupt a national law and the extent to which the industrial relations context has on the impact of the directive. The impact of the directive is also affected by the adequacy or otherwise of remedies and sanctions - the absence of sanction 
being a common complaint in relation to soft law measures. Implementation is also achieved through a parallel social dialogue operating on a consensus basis meaning only one optional measure has been adopted.

Deakin explores recent experience in European company law which, as Clarke's paper has shown, bucks the trend towards new governance techniques. He then draws on this analysis to frame a wider discussion of the prospects for the European social model in the context of market liberalisation. He asks whether there will be an asymmetric approach with the flexible new governance techniques dominant in social and employment policy with hard law imposing a single model (or at least minimum standards) in the field of company law and the internal market? The nuanced answer to this question is salutary for advocates of the open method as a form of flexible governance. Like Scott, he sees new governance as in fact having important continuities with earlier governance practices with reflexive harmonisation a precursor which accommodated diversity of practice among member states. Company law has acquiring its own (modified) form of the open method with the establishment of a high level group of experts to facilitate national convergence, policy learning and to advise the Commission. There is no benchmarking as yet but there is now an institutional framework within which to initiate it. Deakin - consistent with Clarke's analysis - concludes that the prospect of standardisation of company law has receded following the experience of the Takeovers Directive and the fragmentation of national laws that resulted from it. At the same time, there is scope for a reflexive form of governance to allow for policy learning. At the same time, what he sees as a fixation with one mode of best practice based on the US model reduces scope for reflexive governance and diversity. In labour law, there is greater scope for flexibility. In both fields, the role of the European Court and its capacity to change the regulatory environment through broadly liberalising judgments is highlighted. Like Scott, the open method is viewed as a progression and not a completely new method of governance. The challenge is not new or old governance but what level of formality is necessary given the tension between state autonomy and the goal of European integration with the deliberative models at the heart of new governance while playing lip service to national diversity having the capacity to tend toward the imposition of single models. Reflexive harmonisation may in this situation provide a better model. 
Peer Zumbansen's paper takes as his focus the firm and challenges the questionable divide between management and labour that lies at the heart of e.g. .the social partnership in EU law-making. As with Scott and Deakin, the paper attempts to bridge a conventional space this time between corporate and labour law literatures by building on the theory of the innovative enterprise. Through that theory and its insights Zumbansen argues that corporate governance regimes are embedded in differently shaped regulatory frameworks, that in turn are characterised by distinct institutions (formal and informal) and enforcement processes. His paper also points to diversity and challenges the view that there is convergence of corporate governance. He discusses what is meant by corporate governance before examining corporate governance in Germany and the EU and the changing regulatory landscape in both locales. He also notes that the Commission is now differentiating its law making agenda given the political obstacles to convergence. Like Clarke, Deakin and Barrett, he notes the importance of the European Court's case law in prompting reform with that case-law creating regulatory competition in the field of corporate governance. Mindful of the growth of soft law initiatives, he warns that any evaluation of European company law requires an analysis of these regimes as well as legislation. He provides a forward looking agenda to complete the series by drawing on the Varieties of Capitalism literature and complimenting it with a regulatory theory approach and a shift away from conventional bi-polar conceptions of the firm as either a nexus-of-contracts or a social institution towards one that takes into account the particular features of its decision-making processes which are shaped by high-risk assessment of uncertain development trajectories.

Thus the papers end with an agenda for further research in the field of corporate governance with all of them highlighting the absence of a clear dichotomy between hard and soft law with characteristics normally associated with soft law - inextricably bound up with new governance methods - of uncertainty, ambiguity and principles rather than fixed norms also found within classic Community legislation such as the Takeover Directive. Through discussion of implementation as well as the wider theoretical dimensions, the papers also remind us of the challenge of multi-level governance in the European context and the need for ongoing evidence-based research in evaluating the effectiveness and legitimacy of governance regimes. 